\title{
PEMBACAAN AWAL TERHADAP PUISI DAN FOTO DALAM BUKU FOTO JAKARTA ESTETIKA BANAL SEBAGAI SEBUAH CATATAN PERJALANAN
}

\author{
Arif Furqan \\ Sastra Inggris Universitas Brawijaya, Malang \\ E-mail: afurqannn@yahoo.com
}

\begin{abstract}
Abstrak
Tulisan ini hendak menyajikan percobaan pembacaan atas catatan perjalanan dalam bentuk baru. Sebuah buku foto yang kental dengan narasi visual namun juga tetap mengikutsertakan teksteks sastra berupa puisi. Dengan tantangan dari format buku foto, saya mencoba 'membaca' buku ini sebagai sebuah catatan perjalanan dan mengungkapkan teknik-teknik pengkarya dalam menggunakan puisi dan juga foto dalam 'menuliskan' catatan perjalanannya.
\end{abstract}

Kata kunci: Foto, Buku Foto, Puisi, Catatan Perjalanan

\section{Abstrack}

This paper aims to report the reading attempt of a photobook as a new form of travel account. The photobook mentioned is a book rich with visual narration and also enclose few literary texts in form of poem. With the challenge of the photobook form, I will regard the book as a travel account and elaborate the author's technique in 'writing' his travel account.

Keywords: Photo, Photobook, Poem, Travel Account

\section{Pendahuluan}

Catatan perjalanan dalam bentuknya yang paling umum berupa tulisan. Namun tidak pada abad ke-21 ketika fotografi mulai menjelma menjadi medium yang sangat 'praktis' dan available. Fotografi mulai menyokong dan mengakomodasi catatan perjalanan, dan bahkan memperkaya industri turisme. Pengkarya menerjemahkan travel experience tidak hanya menjadi travel text namun juga travel images. Hingga kini banyak sekali catatan perjalanan yang menyertakan foto sebagai 'penggoda' atau 'bukti' visual yang lebih konkret dalam memberitakan kondisi lanskap, budaya, dan masyarakat di suatu tempat, di samping kehadiran tulisan sebagai medium utama dalam menyampaikan informasi.

Ada dua pandangan tentang apa yang dimaksud dengan 'travel writing', sebagaimana yang diungkapkan Thompson (2011: 12-13) bahwa secara ekslusif 'travel writing' adalah 'travel literature' yang merupakan buku-buku yang berisi catatan dari perjalanan yang telah dilakukan, juga narasi personal dari penulis klasik seperti Marcopolo sampai penulis baru seperti Bill Bryson. Di lain pihak, 'travel writing' secara inklusif tidak hanya terbatas pada bukubuku tersebut, namun juga segala bentuk dokumen yang berhubungan dengan perjalanan atau artefak-budaya.

Mempertimbangkan berbagai pendapat dan perkembangan genre hingga masa modern ini, saya setuju dengan Thompson (2011: 26) yang mengungkapkan bahwa garis batas yang mengatur definisi travel writing begitu samar. Ia mengungkapkan bahwa genre ini mempunyai potensi untuk menjadi sangat luas dan melahirkan banyak bentuk baru serta berkembang menjadi sub-genre lainnya seperti buku panduan perjalanan, memoir, tulisan tentang tempat, deskripsi alam, peta, film perjalanan, dan bahkan banyak hal lainnya. Berangkat dari asumsi tersebut, saya mencoba menyeret sebuah buku foto untuk kemudian dibaca sebagai sebuah catatan perjalanan.

Buku foto berjudul Jakarta Estetika Banal karya Erik Prasetya yang terbit pada 2011 lalu dapat disebut sebagai sebuah catatan 
perjalanan. Buku ini menceritakan perjumpaan dan pergelutannya dengan Jakarta dalam cuplikan puisi dan foto. Dalam Jakarta Estetika Banal keseluruhan narasi didominasi oleh foto, sedangkan tulisan yang berupa penggalan puisi hanya menjadi pembuka singkat di awal bab. Buku ini 'mengkondisikan' gabungan antara foto dan puisi sebagai narasi pribadi Erik dalam memandang Jakarta. Menurut bentuknya buku ini memang seharusnya dinikmati melalui foto-fotonya karena narasi yang lebih kaya dan mendetail dibentuk secara visual oleh seri foto di setiap bab. Namun meskipun porsi puisi cenderung sedikit, perannya tidak bisa diacuhkan begitu saja karena tetap saja puisipuisi pembuka tersebut mengambil bagian yang vital dalam pembentukan narasi keseluruhan dari buku ini.

Puisi-puisi yang turut membangun narasi di setiap bab buku tersebut disesuaikan dalam konteks tertentu. Puisi tersebut sengaja dipenggal, dipotong-potong untuk dijadikan sebagai pembuka setiap bab dimana narasi selanjutnya dibentuk oleh foto-foto. Bahkan usaha 'penyesuaian' teks-teks puisi tersebut seringkali memberikan makna yang berbeda dengan puisi aslinya.

Dalam bentuknya sebagai buku foto sekalipun, saya yakin bahwa sebagai catatan perjalanan buku ini tetap mengandung aspekaspek penting sebagaimana yang diungkapkan Thompson (2011: 10) terkait dengan fungsi catatan perjalanan yaitu (1) melaporkan keadaan dunia yang luas, manusia atau tempat-tempat yang tidak familiar, (2) mengungkapkan nilainilai yang dipegang oleh penulis dan asumsiasumsinya, serta (3) mengungkapkan budaya asal penulis dan atau budaya yang dimaksudkan teks.

Begitu pula dalam buku Jakarta Estetika Banal yang saya asumsikan sebagai sebuah catatan perjalanan ini. Dalam relasi antara puisi dan foto, buku ini memiliki fungsi yang sama sebagaimana yang diungkapkan Thompson di atas. Berdasarkan hal tersebut, tulisan ini berniat untuk membahas lebih lanjut tentang transformasi puisi dan posisinya dalam membentuk narasi sebuah catatan perjalanan, dan mencoba menjelaskan teknik pemberitaan dunia, pengungkapan diri, dan representasi liyan dalam relasi puisi dan foto.

\section{Tentang Format Buku Foto Jakarta Estetika Banal}

Dalam buku ini terdapat 127 foto yang terbagi dalam sepuluh bab. Secara garis besar foto-foto yang terdapat dalam buku tersebut bukanlah foto yang yang menekankan keindahan (Le dalam contemporary Fine Arts Photography Vs. Salon Photography), namun lebih menggunakan pendekatan dokumenter yang terfokus pada reportase kehidupan seharihari (daily life reportage). Dengan demikian, buku tersebut tidak menampilkan wajah Jakarta yang indah, namun lebih cenderung menampilkan gambaran 'polos' dan 'spontan' ruang publik dalam rutinitas harian masyarakat Jakarta.

Terdapat enam puisi di antaranya dari Goenawan Muhammad, Chairil Anwar, Zen Hae, Joko Pinurbo, dan Wiji Thukul. Setiap bab diawali oleh penggalan puisi, sehingga terdapat sepuluh puisi pembuka dalam buku ini. Dalam setiap bab yang diawali oleh puisi terdapat setidaknya sepuluh sampai delapan belas seri foto, kecuali bab penutup yang hanya mencantumkan satu puisi dan satu foto.

\section{Puisi Transformasi sebagai 'Kunci' Narasi}

Memang bukan pengkarya buku foto sendiri (Erik) yang menciptakan puisi yang kemudian diselipkan sebagai pembuka tiaptiap bab yang mengangkat narasi tentang Jakarta, tapi dia lah yang memilah-milah puisi dan kemudian memenggal-menggalnya hingga dianggap cocok untuk membimbing narasi visual yang dihadirkan dalam seri foto di setiap bab buku ini. Dalam hal ini boleh dikatakan bahwa pengkarya 'menculik' puisipuisi tersebut dan kemudian mengadopsi serta mentransformasikannya menjadi apa yang 
dikehendaki sebagai pemimpin narasi. Saya menganggap pemotongan baris-baris puisi ini mirip dengan 'memotret' yang memenggal realita dan menampilkan replika yang berupa cuplikan kejadian dalam sebuah foto.

Penggalan bait puisi tersebut seringkali tidak hanya berubah bentuknya, namun juga memberikan nuansa dan makna baru. Dalam buku ini terdapat enam puisi yang kemudian dipenggal-penggal menjadi sepuluh pembuka bab. Karena keterbatasan ruang dan waktu, di sini saya akan menganalisis enam puisi yang dijadikan sebagai contoh studi kasus atas posisi teks puisi terhadap narasi yang dibangun sebelum menuju lebih lanjut pada seri foto.

"Di kota itu gerimis, kata orang, telah jadi logam"

(Prasetya, 2011:19)

Padabab pertamaditampilkan penggalan bagian judul dari puisi Goenawan Muhammad (GM). Penggalan tersebut melepaskan konteks dari keseluruhan puisi yang bercerita tentang romansa sepasang kekasih, menjadi makna yang tereduksi yang kemudian menggiring interpretasi pada gambaran kota yang keras, yang bahkan hujan pun telah menjadi logam. Betapa tidak, bayangkan jika rintik lembut air hujan berubah menjadi serpihan logam yang siap menghujam kulit manusia. Sebagai sebuah pembuka, penggalan puisi tersebut menciptakan ruang interpretasi tentang dunia, tentang kota. Penggalan puisi tersebut membuka interpretasi yang kemudian dihadirkan lewat seri foto, namun sekaligus juga membatasi interpretasi foto pada tataran metafor yang dikehendaki oleh penggalan puisi tersebut. Oleh karenanya, dapat diasumsikan bahwa isi bab ini terfokus pada penggambaran 'kota yang gerimisnya menjadi logam'.

"aku berkisar diantara mereka sejak terpaksa bertukar rupa di pinggir jalan, aku pakai mata mereka"

(Prasetya,2011:37)

Begitu pula yang terjadi dengan penggalan puisi Chairil Anwar berjudul Aku Berkisar Diantara Mereka yang dipotong menjadi bentuk dan makna baru. Puisi romantik yang lahir pada tahun 1941 ini dipotong sedemikian rupa untuk menyatakan diri 'aku' si pengkarya yang berada di antara orangorang Jakarta. Dengan menyertakan penggalan sedemikian rupa, pengkarya yang juga narator bertujuan untuk menjelmakan dirinya dalam 'aku' lirik yang berbaur dan menjadi bagian dari 'mereka', orang-orang Jakarta. Dalam bab ini puisi mengawal interpretasi untuk memperhatikan posisi 'aku' di antara 'mereka'. Dengan demikian, dapat diasumsikan bahwa di sini narator terfokus untuk mengungkapkan keberadaan diri di antara orang-orang Jakarta.

$$
\begin{aligned}
& \text { "mereka bangun kota-kota } \\
& \text { baru di dalam kaca" } \\
& \text { (Prasetya,2011:51) }
\end{aligned}
$$

Bait tersebut 'dipenggal' dari puisi berjudul taman kanak-kanak yang ditulis oleh Zen Hae pada tahun 1992. Secara singkat puisi yang utuh menceritakan tentang generasi baru yang telah berubah dan membuat kekacauan di dunia. Namun, penggalan yang dihadirkan sebagai pembuka bab ketiga ini memberikan ungkapan yang telah tereduksi. Terdapat dua unsur penting yang terkandung dalam bait tersebut, yaitu 'mereka' dan 'kota-kota', sehingga bisa diasumsikan bahwa sebagai pembuka bab, puisi ini menggiring fokus pada 'mereka', orang-orang Jakarta, dan 'kota' yang mereka bangun. Kata 'mereka' memisahkan posisi narator dengan orang Jakarta lainnya. Memandang mereka berarti menampilkan sosok orang-orang Jakarta yang berbeda dari narrator, dan kota-kota mereka adalah kota yang dibangun oleh orang yang bukan narator. 
Dengan demikian, dalam bab ini penggalan puisi tersebut memfokuskan perhatian pada pandangan narator tentang masyarakat Jakarta dan kota yang dibangun oleh mereka.

“sopirnya sepuluh
kernetnya sepuluh
kondekturnya sepuluh
pengawalnya sepuluh
perampoknya sepuluh
penumpangnya satu”
(Prasetya,2011:71)

Setelah dipenggal, puisi Joko Pinurbo tersebut memang terasa hanya seperti ungkapan biasa, direduksi dari judul dan badan puisi secara keseluruhan. Penggalan tersebut mengindikasikan sebuah alat transportasi yaitu sebuah bus yang ditandai dengan adanya sopir, kernet, kondektur, dan penumpang. Dalam konteks membicarakan tentang Jakarta, maka puisi tersebut sedang menggiring perhatian pembaca pada penggambaran tentang alat transportasi di kota tersebut. Penggalan puisi tersebut menyimpan efek hiperbolik pada penekanan jumlah yang dilebih-lebihkan, seolah sedang mengesankan bahwa transportasi tersebut begitu kacau dan sesak. Semua atribut yang disebutkan berjumlah sepuluh merupakan penghuni wajib bus kota yang seolah secara alami menjadi bagian dari alat transportasi tersebut.

Frase 'penumpang satu' boleh dikatakan sebagai orang yang lain bagi sopir, kernet, kondektur, pengawal, dan perampok. Sosok penumpang tergambar sebagai orang biasa. Satu penumpang di antara puluhan 'penghuni' bis kota memberikan kesan bahwa naik bus di Jakarta sangat sesak, tidak nyaman, belum lagi resiko bertemu perampok atau pencopet di bus. Penggalan puisi tersebut memfokuskan pada kondisi bus sebagai alat transportasi di Jakarta yang begitu sesak dan kacau. "anak-anak membangun sorga baru di sepanjang trotoar-tanpa imb dan izin lokasi"

(Prasetya,2011:85)

Seperti pada penggalan puisi pembuka di bab ketiga, bait di atas juga merupakan penggalan dari puisi taman kanak-kanak. Baik kedua penggalan tersebut mempunyai makna yang berbeda dengan puisi aslinya. Bahkan penggalan di bab ketiga juga mempunyai makna yang berbeda dengan penggalan puisi di atas. Subjek pada penggalan puisi sebelumnya berkisah tentang 'mereka' yang membangun kota, sedangkan yang di atas bercerita tentang anak-anak yang membangun sorga di pinggiran jalan. Sosok 'mereka' terkesan perkasa karena kemampuannya membangun kota, sedangkan sosok 'anak-anak' terkesan putus asa dan bahkan utopis karena pembangunannya tidak disertai IMB (Izin Mendirikan Bangunan) dan izin lokasi.

Dari sini dapat disimpulkan bahwa 'mereka' dan 'anak-anak' adalah subjek yang berbeda, setidaknya dalam konteks kelas. Merujuk pada kutipan tersebut, sebagai pembuka dapat diasumsikan bahwa penggalan puisi tersebut berfokus pada penggambaran 'anak-anak' yang berarti liyan bagi narator, juga penggambaran 'sorga baru' yang memberitakan dunia yang berusaha dibangun oleh 'anak-anak' tersebut.

Meninjau analisis singkat tentang penggalan-penggalan puisi di beberapa bab dalam buku Jakarta Estetika Banal, dapat disimpulkan bahwa setiap penggalan puisi memiliki fungsi yang hampir sama, yaitu sebagai pengantar yang 'mengawal' interpretasi dalam menikmati narasi visual yang ditampilkan foto pada tiap-tiap bab. Penggalan-penggalan puisi di atas memberikan metafora yang merupakan subjektivitas pengkarya sebagai narator. Dibandingkan dengan teks puisi secara keseluruhan, memang makna yang dihadirkan begitu berbeda. Strategi pemenggalan tersebut 
rupanya memang sengaja ditempuh untuk mengarahkan interpretasi keseluruhan dari gabungan teks dan foto. Unsur-unsur yang tertanam dalam penggalan puisi tersebut menjadi semacam kata kunci (keyword) untuk menerjemahkan narasi visual foto.

\section{Relasi Puisi terhadap Foto dalam Pemberitaan Dunia}

Saya hendak mengutip sedikit mengenai 'Pesan Fotografis'Barthezbahwa foto setidaknya 'bersetubuh' dengan teks (dalam kasus ini adalah puisi pembuka) untuk menghadirkan informasi (Barthez,2010:10). Pada hakikatnya imaji fotografis merupakan sebuah analogon, tiruan, yang sempurna dari realitas, sehingga dalam tataran ini foto merupakan duplikasi dari apa yang disaksikan oleh fotografer. Analogon tersebut bersifat denotatif atau objektif, sementara sebaliknya pesan fotografis sesungguhnya bersifat konotatif atau sarat muatan. Tanpa merendahkan fungsi foto, saya tidak akan membahas lebih dalam mengenai pesan fotografis pada pembahasan ini. Dalam bab ini saya akan membatasi pembahasan pada pengaruh teks puisi pembuka pada fotofoto yang ditampilkan dalam setiap bab yang merupakan penggambaran dunia.

Memperhatikan posisi dan fungsi teks dalam membentuk narasi bersama dengan seri foto yang ditampilkan dalam setiap bab, maka sementara saya simpulkan bahwa fokus penggambaran dunia dibuka oleh teks puisi, dan kemudian foto dihadirkan di bawah pengaruh teks puisi. Puisi pembuka 'menunggangi' foto dengan memberikan ruang metafor sebagai ruang interpretasi bagi foto-foto dalam setiap bab. Sementara itu, foto dalam setiap bab berfungsi sebagai 'representasi' yang menghadirkan kembali pengalaman visual narator dalam melihat dunia, sehingga dapat dikatakan bahwa sebagai sebuah analogon, seri-seri foto tersebut merupakan medium penggambaran dunia sebagaimana yang dilihat oleh fotografer.
Dalam beberapa bab, teks puisi sebagai pembuka mengandung muatan metafor yang merupakan kesan subjektif narator dalam menggambarkan dunia. Seperti yang telah dibahas sebelumnya, penggalan puisi tersebut sengaja dikondisikan untuk mengakomodasi ekspresi subjektif narator. Dengan menampilkan potongan dari puisi tersebut narator hendak menerjemahkan kesan emosionalnya dalam memandang kota (Jakarta). Sebagai satu narasi, relasi teks dan foto tersebut menjadi relasi ungkapan subjektif dan replika realitas (yang di satu sisi objektif, namun di sisi lain mengandung subjektifitas dari fotografer) (Barthez,2010:10). Oleh karenanya, di sini teks memiliki peran yang sangat penting, yaitu menciptakan ruang interpretasi subjektif yang akan diisi oleh seri foto.

Sebagai pemberitaan dunia, relasi teks dan foto tersebut membangun narasi tertentu dalam setiap bab-nya. Seperti pada bab pertama yang dibuka dengan cuplikan puisi GM, 'Di kota itu gerimis, kata orang, telah jadi logam', dan dalam halaman-halaman berikutnya narator menghadirkan beberapa foto tentang kondisi lanskap kota dan masyarakat Jakarta. Berikut adalah salah satu foto dalam bab ini.

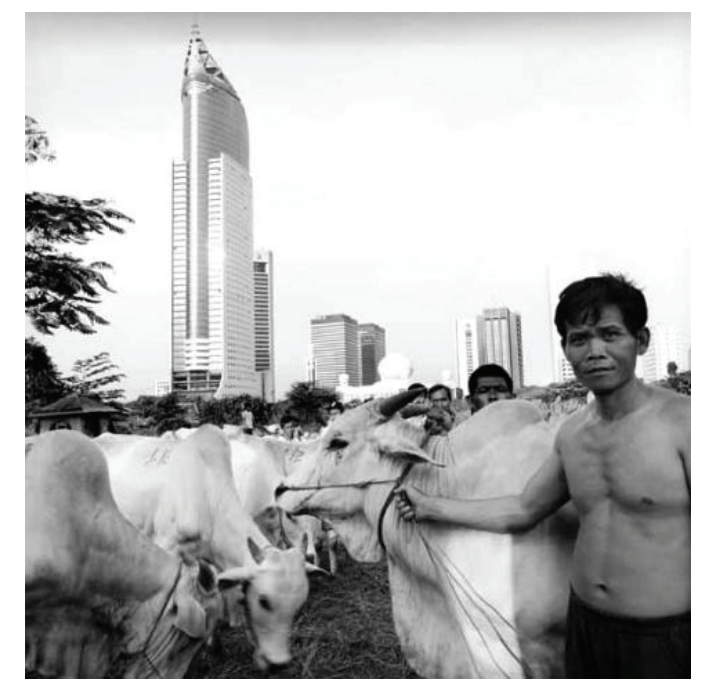

Pedangang sapi kurban di daerah Karet, sisi barat Gedung BNI 46 di latar. Jakarta Estetika Banal: 33 
Foto tersebut merupakan salah satu contoh foto yang memberikan penggambaran dunia dalam bab ini. Gerimis yang telah menjadi logam merupakan kesan subjektif akan kerasnya kehidupan di Jakarta. Foto tersebut menampilkan dampak urbanisasi yang mulai menggeser lahan-lahan lapangan kerja yang bersifat tradisional dan yang modern, seperti yang tampak pada foto dimana bangunan megah membayang-bayangi pasar tradisional.

Selain itu, penggambaran dunia dengan pola yang sama juga muncul di bab ketiga. Dengan dibuka oleh cuplikan puisi Zen Hae, 'mereka bangun kota-kota baru di dalam kaca', narator menampilkan foto-foto orang dan kegiatannya di dalam Mall. Puisi pembuka foto yang sebelumnya masih abstrak dijelaskan oleh visual foto yang menampilkan aktivitas manusia di dalam Mall sebagai kota dalam kaca. Berikut merupakan salah satu foto dari beberapa seri foto dalam bab ini.

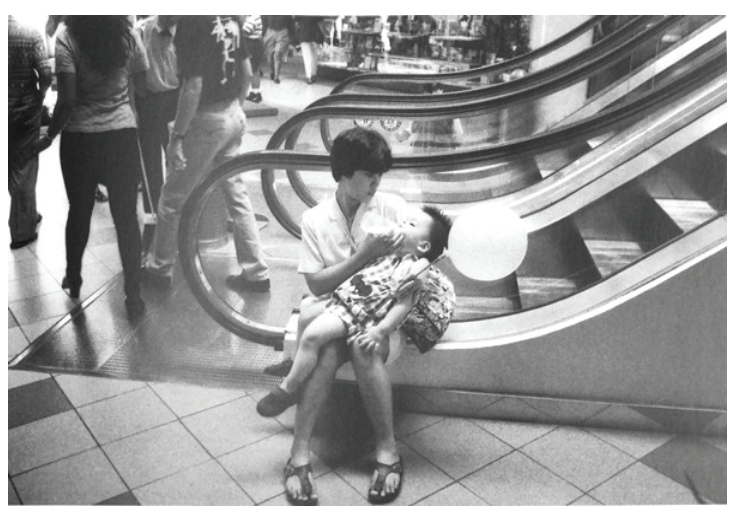

Pondok Indah Mall, 1996. Jakarta Estetika Banal: 65

Dalam foto tersebut narator sedang memberitakan dunia dengan menghadirkan kondisi masyarakat yang berada di dalam Mall. Penggalan puisi pembuka pada dua bab ini memiliki unsur yang sama, yaitu penekanan terhadap 'kota'. Hal tersebut bertujuan untuk menciptakan indikasi akan isi foto masingmasing bab yang terfokus pada pembicaraan tentang keadaan kota, secara spesifik pada Mall. Dengan demikian, dua bab ini bisa dikatakan mengarahkan pembaca pada pemberitaan dunia dengan menggunakan teks puisi untuk 'mengawal' dan mengarahkan interpretasi.

\section{Relasi Puisi terhadap Foto dalam Pengungkapan Diri dan Liyan}

Penggambaran kedua foto pada pembahasan sebelumnya tidak hanya memberitakan tentang dunia, tapi juga menyiratkan diri narator dalam memandang orang-orang yang disoroti dalam foto tersebut. Namun,puisipembukamengarahkaninterpretasi sehingga terfokus pada penggambaran dunia. Sebagai contoh, pada bab sebelumnya dimana teks puisi GM dan Zen Hae menyertakan kata kunci 'kota' untuk memfokuskan interpretasi visual pada penggambaran kota. Secara mandiri foto-foto yang ditampilkan tidak hanya berbicara mengenai kota, namun juga orangorangnya. Namun, dengan strategi pengantar puisi, narator bisa 'mengendalikan' secara halus arah interpretasi sehingga tidak bocor dalam memaknai simbol-simbol visual dalam foto.

Begitu pula dalam pengungkapan diri, terdapat strategi tertentu yang mengarahkan narasi yang dibangun oleh teks dan foto. Sebagai contoh pada bab kedua yang dibuka dengan cuplikan puisi Chairil Anwar berikut.

\section{"aku berkisar diantara mereka sejak terpaksa bertukar rupa di pinggir jalan, aku pakai mata mereka" (Prasetya:37)}

Dengan penggalan puisi tersebut narator hendak menempatkan dirinya dalam 'aku' lirik, sehingga relasi yang terbentuk antara 'aku' dan 'mereka' menjelma menjadi representasi antara narator dan liyan. Kekuatan yang dibentuk oleh teks ini merujuk pada prinsip saksi mata (eyewitness) dari fotografi, dimana foto-foto yang ditampilkan merupakan sudut pandang 'aku'. Oleh karenanya, meski tidak ada kehadiran sosok 'aku' dalam bingkai foto, 
namun keberadaan foto tersebut merupakan bukti bahwa 'aku' sedang memandang 'mereka' atau orang-orang dalam foto tersebut. Berikut contoh foto yang terdapat pada bab kedua ini.

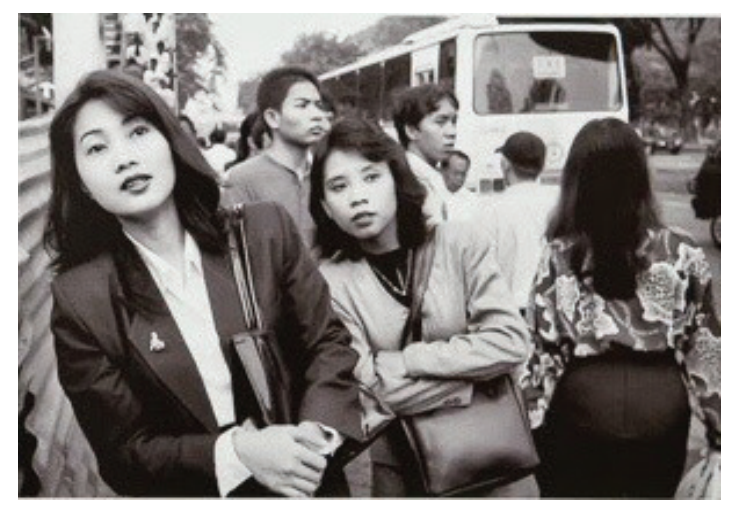

Jalan Sudirman, 1997. J akarta Estetika Banal: 41

Tidak ada kehadiran sosok narator dalam foto tersebut. Namun secara alami sifat dari sebuah foto memposisikan diri narator sebagai orang yang memandang melalui lensa kamera dan kemudian memotretnya. Dengan begitu, teks pembuka di awal bab ini sedang berusaha merujuk pada sifat alami sebuah foto, yakni menempatkan narator dalam posisi 'aku' fotografer, sehingga kehadiran foto tersebut mengkonfirmasi kehadiran fotografer sebagai orang yang memotret. Dengan menampilkan teks tersebut, narator seolah ingin mengobati ketidakhadiran dirinya (absence) secara visual dalam foto tersebut, sehingga dalam memberitakan kota Jakarta diri narator secara teknis hadir di balik kamera. Teks puisi tersebut bertugas untuk mengikat foto dalam hubungannya dengan narator sebagai pencipta foto.

Relasi 'aku' dan 'mereka' tentunya juga merupakan implikasi akan pembedaan antara diri dengan liyan. Usaha menyoroti perbedaan antara diri dengan orang dari kultur yang berbeda (liyan) disebut sebagai othering (Thompson,2011:132). Dalam foto tersebut selain memposisikan diri di antara mereka, narator juga sedang melakukan othering pada orang yang dipotretnya. Dalam bab ini foto yang banyak dihadirkan adalah kaum pekerja, terutama wanita. Sebuah foto yang menampilkan seorang gadis kecil pengamen dari dalam mobil ini merupakan contoh tepat yang menggambarkan posisi narator dan juga orang yang sedang disorotinya.

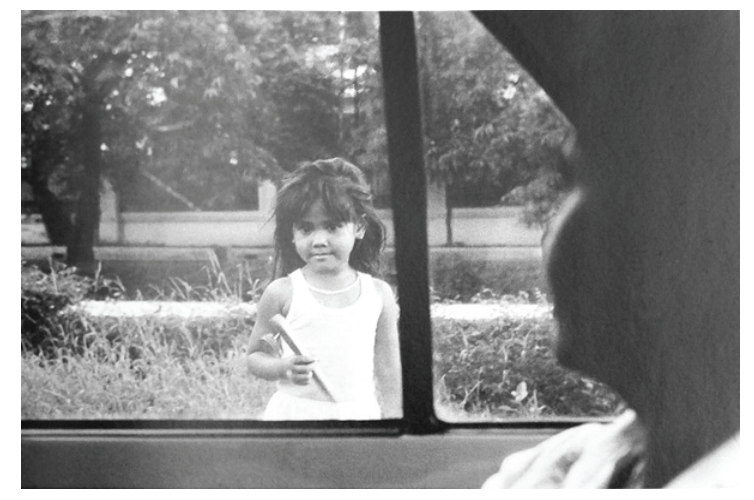

Jalan Sutan Syahrir, December 1999. Jakarta Estetika Banal: 49

Foto-foto tersebut jelas sekali menyoroti persoalan tentang kelas, dimana dalam beberapa bingkai narator menampilkan wanita-wanita pekerja kantoran sedang menunggu bus yang merupakan representasi buruh kelas menengah. Di halaman berikutnya narator menghadirkan foto gadis kecil pengamen yang difoto dari dalam mobil. Posisi tersebut menegaskan posisi antara narator yang juga fotografer yang sedang berada di dalam mobil berbanding dengan foto gadis pengamen. Perbedaan tersebut diindikasikan oleh perbedaan kelas antara narator dengan sosok yang sedang dipotretnya. Dengan demikian othering yang menciptakan jarak antara 'aku' dan 'mereka' muncul dalam pembedaan terhadap kelas.

Selain itu bab kelima juga menggambarkan othering yang dilakukan dengan menampilkan foto-foto tentang pekerja anak-anak. Dalam pembuka bab ini narator menampilkan penggalan puisi Zen Hae sebagai pembuka. Puisi tersebut menyebutkan bahwa di kota ini 'anak-anak membangun sorga baru di sepanjang trotoar-tanpa imb dan izin lokasi' 
(Prasetya,2011:85). Penggalan puisi tersebut memberikan metafora yang merujuk pada anak-anak di jalanan. Selanjutnya dalam bab ini narator menghadirkan foto-foto pekerja anak, di antaranya adalah foto anak-anak yang bekerja di pembakaran arang (Prasetya,2011:87), pekerja anak di penghancuran kapal tua (Prasetya,2011:93), pekerja anak di pertanian kerang hijau (Prasetya,2011:94), dan dua foto tentang anak-anak yang menjadi ojek payung (Prasetya,2011:104-105).

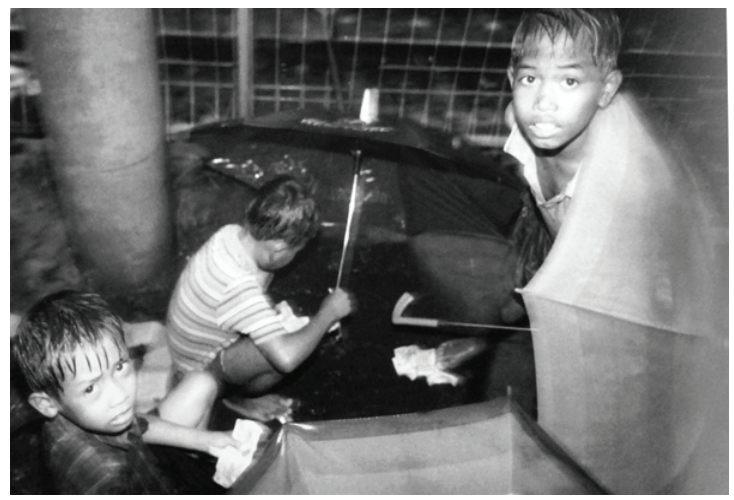

Ojek Payung. Stasiun Tebet, 1993. Jakarta Estetika Banal: 104

Foto-foto tersebut menggambarkan pandangan narator dalam memandang masyarakat Jakarta. Menggunakan fotofoto tersebut, ia seolah sedang menyoroti penduduk Jakarta yang ia jumpai berdasarkan profesinya. Merujuk pada kondisi pekerja anak yang merupakan para pekerja jalanan, narator menggunakan kelas sebagai pembeda antara dirinya dan orang yang digambarkannya.

Bukan hanya masyarakat kelas bawah yang disorotinya, namun juga masyarakat kelas atas. Seperti yang muncul pada bab kesembilan yang diawali dengan cuplikan puisi Zen Hae berikut.

"kota-kota lapar. letih dan tidur tik...tik...tik... hujan menombaki senja malam jatuh dengan ubun terluka" (Prasetya,2011:161).
Dalam bab ini selanjutnya narator memberikan foto-foto tentang kalangan kelas atas yang sedang mencari hiburan di diskotik dan klub malam. Berangkat dari cuplikan puisi di atas, narator seolah mengesankan bahwa kalangan kelas atas adalah orang-orang yang ubun-ubunnya terluka yang kemudian mengobati lukanya dengan hiburan malam.

Berdasarkan dua kecenderungan othering di atas, dapat dilihat bahwa narator membedakan dirinya dan liyan dalam pandangan kelas. Ia menyoroti masyarakat kelas bawah dan juga masyarakat kelas atas. Hal itu menunjukkan posisi narator yang berada di antara kedua kelas tersebut, yaitu kelas menengah. Seperti yang tertulis pada penutup buku ini bahwa 'kalangan menengah adalah kelas yang menjadi asal sebagian besar fotografer profesional' (Prasetya,2011:187), dengan begitu kalimat dari pengkarya sendiri mengkonfirmasi posisi dirinya sebagai kalangan menengah yang melihat ke atas dan ke bawah.

\section{Kesimpulan}

Dalam buku foto Jakarta Estetika Banal, teks-teks puisi dihadirkan untuk mengarahkan interpretasi sehingga representasi kota yang dimaksudkan pengkarya dapat ditangkap oleh pembaca. Dalam pembacaan terhadap buku tersebut, relasi yang terbentuk dari puisi dan foto memunculkan pola tersendiri dalam penggambaran dunia. Teks puisi di setiap bab menyediakan ruang metafora yang mengawal interpretasi pada seri foto, mewarnai 'kepolosan' (analogon) foto sehingga menguatkan subjektifitas narator yang juga sebagai fotografer. Foto menyimpan 'stok data' dari cuplikan realita yang interpretasinya diarahkan oleh teks puisi.

Sementara itu, dalam pengungkapan diri dan representasi liyan, secara tidak langsung teknis fotografi itu sendiri menjelaskan posisi 'aku' narator sebagai fotografer, dan orang yang difoto sebagai liyan. Namun, seperti kasus bab kedua yang menggunakan penggalan 
puisi Chairil Anwar, puisi berperan untuk menggiring kembali atau mengingatkan logika teknis tersebut, sehingga diri narator yang absen di dalam foto secara rasional dianggap hadir sebagai orang yang memotret dan memandang liyan.

Penggambaran liyan seperti pula penggambaran dunia juga menggunakan peran penting teks puisi dalam 'mengawal' interpretasi. Penggambaran diri dan liyan dalam beberapa bab buku ini menggunakan kata kunci 'aku' dan 'mereka' untuk memfokuskan perhatian pada perbedaan posisi narator dan orang yang sedang digambarkannya. Puisi tersebut membantu mengarahkan interpretasi foto sehingga terfokus pada pembedaan narator dan liyan.

Setelah melakukan pembacaan awal atas buku foto tersebut, dapat saya tarik kesimpulan sementara bahwa dengan formatnya, buku foto menyimpan banyak potensi untuk dikaji lebih lanjut, terutama mengingat bahwa media komunikasi antara pengkarya dan pembaca telah diperkaya dengan tambahan media lain seperti fotografi. Dalam buku ini tulisan tidak lagi menjadi media utama dalam mengungkapkan narasi, sebab foto mengambil alih secara dominan narasi tersebut. Namun, mengingat bahwa tulisan ini merupakan pembacaan awal buku foto sebagai sebuah catatan perjalanan, saya merasa banyak sekali kajian-kajian yang dapat dikembangkan lebih lanjut dengan lebih memperhatikan fungsi masing-masing medium dalam mengungkapkan narasi. Munculnya bentuk catatan perjalanan seperti buku foto akan memperkaya variasi dalam genre ini. Karya-karya tersebut merupakan konsekuensi dari perkembangan teknologi yang tak terhindarkan, sehingga membawa genre travel writing ke dalam ranah kajian baru yang lebih luas.

\section{Daftar Pustaka}

Barthez, Roland. 2010. Imaji Musik Teks (diterjemahkan oleh Agustinus Hartono). Yogyakarta: Jalasutra.

Prasetya, Erik. 2011. Jakarta Estetika Banal. Jakarta: Kepustakaan Populer Gramedia.

Thompson, Carl. 2011. Travel Writing. New York: Routledge.

\section{Sumber Internet}

Lee, T.O. (tanpa tanggal). Contemporary Fine Arts Photography Vs. Salon Photography. Artikel internet diakses pada $31 \mathrm{Mei}$ 2015 melalui http://www.tolee.com/ $\mathrm{html} /$ phot230.htm 